\title{
Consumer Preference for Certified Sustainable Palm Oil with Environmental Sustainability Attributes: A Choice Experiment Approach
}

\author{
SULEIMAN ALHAJI DAUDA ${ }^{1}$, SHAUFIQUE FAHMI SIDIQUE ${ }^{2}$, TEY YEONG SHENG ${ }^{3}$, \\ MARCEL DJAMA ${ }^{4}$ \\ ${ }^{1}$ School of Business and Economics, UNIVERSITI PUTRA MALAYSIA, MALAYSIA. \\ E-mail: Suleh2011@gmail.com \\ ${ }^{2}$ School of Business and Economics, UNIVERSITI PUTRA MALAYSIA, MALAYSIA. \\ E-mail: shaufique@upm.edu.my \\ ${ }^{3}$ Institute of Tropical Agriculture and Food Security, UNIVERSITI PUTRA MALAYSIA, MALAYSIA. \\ E-mail: tyeong.sheng@gmail.com \\ ${ }^{4}$ Institute of Tropical Agriculture and Food Security, UNIVERSITI PUTRA MALAYSIA, MALAYSIA. \\ E-mail: marcel.djama@cirad.fr
}

\begin{abstract}
Increasing consumer preference for sustainable palm oil necessitates a paradigm shift towards certified sustainable palm oil (CSPO), and the introduction of CSPO cooking oil, with environmental attribute certification and eco-labelling, will be hallmarks of the necessary sustainability standard. In this study, we applied a choice experiment to investigate supply side consumer preferences, and to estimate willingness to pay (WTP) for cooking oil certified under Roundtable for Sustainable Palm oil (RSPO). Sustainability standards for the palm oil industry were introduced to address environmental issues, such as biodiversity conservation, and the harmful reduction in $\mathrm{CO}_{2}$ emission. To achieve this, we examined Malaysian consumer knowledge of the CSPO, and investigated its influence on their choice of palm oil supply value chain model, considering biodiversity conservation, $\mathrm{CO}_{2}$ reduction and the willingness to pay (WTP). The main finding of this study indicated that Malaysian consumers are willing to pay more than a $5 \%$ price premium for RSPO certified palm (cooking) oil, while the most prioritized attributes is the mass balanced supply chain model that included both moderate levels of biodiversity conservation and of $\mathrm{CO}_{2}$ emission.
\end{abstract}

Keywords Sustainability, Certified Sustainable Palm oil, Roundtable on Sustainable Palm oil, Choice Experiment:

JEL Classification: Q51 


\section{Introduction}

Consumer demand, and preferences are important sustainability factors for businesses to consider, when making procurement and production decisions (Gassler \& Spiller, 2018). A global paradigm shift is underway, in the quest for sustainable production and consumption, and the best way to identify sustainable product is through certification and eco-labelling. For this reason, markets have been flooded with numerous voluntary certification and labelling schemes, each with differentiated products, and utilizing a variety of labels of sustainability processes (Smith, 2008). Many eco-labels have been introduced, for a variety of agricultural, food products, including Cocoa, Rubber, Coffee, Soy, palm oil etc.

Roundtable for sustainable palm oil (RSPO) is a global voluntary sustainability palm oil standard agency, established in 2004 by stakeholders in palm oil industry, with a remit to define sustainability standards, and establish both certification and eco-labelling within the palm oil supply chain (Disdier et al., 2013). Consumers can identify RSPO supply chain certification, as product labels or claims, which indicate either that the product contains 100\% RSPO certified, or mixed RSPO 1-99\% certified product (Hinkes \& Christoph-Schulz, 2020). Use of this service provides consumers with additional options in trade off decisions of sustainability against price (De Jonge et al., 2015, (Qureshi et al., 2020).

Palm oil for cooking has been particularly selected for this study, because is the most consumed vegetable oil, being both cheap and readily available, and widely used for both food and non-food purposes (Noor and Hua, 2016). The current study focuses on the following issues; the supply value chain certification model used by RSPO for segregation, tracking, and tracing $100 \%$ RSPO certified palm cooking oil, Mass balance/Book and claim as 1-99\% mixed certified RSPO palm cooking oil, and their impacts on biodiversity conservation, level of $\mathrm{CO}_{2}$ emissions, and premium pricing.

Palm oil is the world's leading vegetable oil, of which $80 \%$ of production comes from Southeast Asia, particularly Indonesia and Malaysia. Such nations are considered to be the largest global hotspots for a variety of species of endangered, or threatened fauna and flora (Bateman et al., 2015). Upsurge in the demand for vegetable oil, as a result of population growth, has expanded global, fat-containing food consumption. This increase, exacerbated by the advent of its usage in biofuels, has induced landuse change from tropical forest to oil palm production, (Jones et al., 2018). This scenario exemplifies a typical trade-off between ecology and economy, where tropical forest conservation is set in conflict with much needed economic return from land conversion to oil palm agriculture, with the result that biodiversity is being threatened or endangered, while a lot of greenhouse gas (GHG) is emitted, particularly $\mathrm{CO}_{2}$, during the processes of production through consumption of palm oil. Land use-change as a result of expansion in agriculture and oil palm plantations is one of the major reasons for deforestation witnessed in the tropic of Southeast Asia (Bateman et al, 2015).

Knowledge is lacking regarding the preference of Malaysians for sustainable palm oil, or WTP faced with a price premium for conservation grade-palm oil. This study explores Malaysian consumer knowledge of CSPO, and assess their WTP price premium for RSPO certified palm oil.

\section{Literature Review}

Economic choice theory suggests that consumer preferences, that are based on their behavioural intention, can be influenced by perception and attitude toward products. The rational consumer sets out to maximize utility, given his/her budget, and other potential constraints (Hinkes \& ChristophSchulz, 2020). Based on this framework, consumer knowledge of the CSPO is examined. Although it has not yet been concluded whether sustainability labelling influences consumer decision making when buying palm oil products, other factors, such as motivation, perception, knowledge, previous experience, and trust in certification and labelling, may play significant roles.

One of the current problems associated with palm oil production, is the development of its sustainable standard (Vergura et al., 2019), while buying only certified sustainable palm oil has been identified as the most effective means to reducing the adverse effects of palm oil production 
(Sundaraja et al., 2020), and this will support standard development. Issues related to sustainability of palm oil have previously been viewed from the production perspective. The current study employed a choice experiment to determine consumer preference for an RSPO supply value chain, and estimate the WTP a premium for certified palm oil, that is endowed with environmental attributes viz conserving biodiversity, and reduction of $\mathrm{CO}_{2}$ emissions, in Malaysia.

To effectively reduce the impact of oil palm on the environment, by conserving biodiversity and reducing the harmful $\mathrm{CO}_{2}$ emissions, strategy should seek to incentivise the RSPO certified members who have adopted the supply value chain model. Members need incentives, since they can incur significant costs, especially in terms of forgone income, for conservation of both primary and secondary forest (Bateman et al., 2015). Although the demand for and supply of Certified sustainable palm oil is slow (Gassler \& Spiller, 2018), there is also limited knowledge amongst consumers of the impact of palm oil on the environment (Giam et al., 2016). However, recent studies have indicated increasing consumer demand for environmentally friendly products, and readiness on the part of manufacturers to produce, and market eco-friendly products (Loureiro \& McCluskey, 2000; Bougherara and Grolleau, 2004). Firms are then compelled to indicate the presence of a particular quality or specific attribute attached to their product, that in turn serves as potential for price premium (Caswell \& Padberg, 1992).

Certification and eco-labelling are voluntary, market-oriented schemes supported by only limited government regulation (Loureiro \& McCluskey, 2000), which is often used to induce sustainable consumption and production. Therefore, for a scheme to succeed in attracting consumers to choose certified green products, it must also be incentive compatible for growers and manufacturers. The production and marketing practices in value chain must either be cost competitive, with uncertified processes, and / or consumers must be attracted and willing to pay a price-premium for costlier certified products (Jensen et al., 2004).

Sustainability has been related to the studies of preferences for sustainable palm oil in different ways. To this end, RSPO have commodified the market for palm oil by introducing the market for certification, as elucidated in study by Richardson (2015). From another perspective, Bateman et al. (2015) related sustainability of palm oil with conservation of Tiger species in Indonesia. Giam et al. (2016) related palm oil sustainability with "deforestation-free palm oil products" in Malaysia and Japan. Borrello et al. (2019) evaluated sustainability from "palm oil-free label" products, and identified labelling as the driver of consumer preference. Vergura et al. (2019) also evaluated consumer perception for palm oil products by assessing "palm oil free", in comparison with "with sustainable palm oil" labelled products. Ostfeld et al. (2019), and Gassler \& Spiller (2018) explored the concept of palm oil sustainability, and impact of RSPO certification and the supply value chain model. Hinkes \& Christoph-Schulz (2020) studied chocolate cookies made with palm oil, exploring consumer preferences for "palm-oil-free" cookies. Lange \& Coremans (2020), explored the influence of consumer knowledge of products containing palm oil in reducing consumption demand for palm oil, with a view to inducing sustainable palm oil consumption.

\section{Methodology}

\subsection{Study Area}

The Klang Valley region, located in peninsular Malaysia, has an area of $2843 \mathrm{~km}^{2}$, and a total population of 6.187 million in 2010, with population expected to grow to 10 million by 2020 (Chiu et al., 2014). Klang Valley is selected as the study area because it is one of the most developed regions in Malaysia, due to rapid urbanisation, population growth, and industrial activities (Kaffashi et al., 2016).

Klang Valley has been divided into geographical clusters with sampling from 1) Kuala Lumpur, 2) Klang; 3) Kajang; 4) Subang Jaya; 5) Petaling Jaya; 6) Selayang; 7) Shah Alam; 8) Ampang Jaya; 9) Putrajaya; 10) Sepang; 11) Serdang; 12) Gombak; and 13) Rawang. The survey locations were randomly selected from public places including shopping malls, hospitals, households, restaurants, supermarkets, and hypermarkets, train station, place of worship, etc. In these locations, the sample of 
322 consumers were randomly interviewed via face-to-face questionnaire. Systematic random sampling, a form probability sampling method was used, it provides that each consumer has a chance to be selected at regular intervals to form a sample. Consumers are chosen from the targeted population from random locations, commencing from a random starting point, and continuing by choosing other consumer after a fixed sampling interval.

\subsection{Survey Design}

Table 1. Attributes of Choice Experiment

\begin{tabular}{|c|c|c|}
\hline Attributes & Levels & Explanations \\
\hline \multicolumn{3}{|r|}{ Roundtable on sustainable palm oil (RSPO) } \\
\hline RSPO 1 & Opt-out & Not willing to participate in the choice of this attribute \\
\hline RSPO 2 & 1 - 99\% RSPO Mixed & $\begin{array}{c}\text { This attribute represents the RSPO supply chain attribute of "Mass } \\
\text { balance"/"Book and claim". Palm oil processed under this supply value } \\
\text { chain model is a mixture of certified and conventional palm oil processed } \\
\text { together. }\end{array}$ \\
\hline RSPO 3 & $100 \%$ RSPO certified & $\begin{array}{l}\text { This attribute represents the RSPO supply chain attribute of } \\
\text { "segregation"/"trace and track". Palm oil processed under this supply chain } \\
\text { model are } 100 \% \text { certified with no mix between certified and conventional. }\end{array}$ \\
\hline \multicolumn{3}{|r|}{ Biodiversity Conservation (BIO) } \\
\hline $\mathrm{BIO} 1$ & Opt-out & Not willing to participate in the choice of this attribute \\
\hline $\mathrm{BIO} 2$ & Moderate conservation & $\begin{array}{l}\text { Conservation of biodiversity under this provision allows the oil palm } \\
\text { growers to allocate minimum space in or by the plantation as a hotspot for } \\
\text { biodiversity. }\end{array}$ \\
\hline $\mathrm{BIO} 3$ & High conservation & $\begin{array}{l}\text { Conservation of biodiversity under this provision allows the oil palm } \\
\text { growers to allocate relatively big space in or by the plantation as a hotspot } \\
\text { for biodiversity }\end{array}$ \\
\hline \multicolumn{3}{|r|}{ Carbon dioxide emission (COE) } \\
\hline COE 1 & Opt-out & Not willing to participate in the choice of this attribute \\
\hline COE 2 & Moderate emission & $\begin{array}{c}\text { Activities of oil palm production entail emissions of } \mathrm{CO}_{2} \text {. Milling, } \\
\text { transportation, processing and cultivation of plantation are all associated } \\
\text { with } \mathrm{CO}_{2} \text { emissions. To minimize such emissions requires the employment } \\
\text { of moderate technology, that will provide a better alternative to high } \\
\text { emissions. }\end{array}$ \\
\hline COE 3 & Low Emission & $\begin{array}{l}\text { Activities of oil palm production entail emission of } \mathrm{CO}_{2} \text {. Milling, } \\
\text { transportation, processing and cultivation of plantation are all associated } \\
\text { with } \mathrm{CO}_{2} \text { emissions. To minimize such emissions requires employment of } \\
\text { efficient technology, that will provide a better alternative to high emissions. }\end{array}$ \\
\hline \multicolumn{3}{|r|}{ COST (Price Premium) } \\
\hline & $0 \%$ & Not willing to participate in the choice of this attribute \\
\hline & $3 \%$ & \multirow{2}{*}{$\begin{array}{l}\text { Price premium is paid on environmentally friendly products. The premium } \\
\text { in this research is to be paid by consumers, on the demand-side, to the } \\
\text { RSPO supply side participants, whom adhere to the principles of } \\
\text { conservation of biodiversity and minimization of harmful } \mathrm{CO}_{2} \text { emissions. }\end{array}$} \\
\hline & $5 \%$ & \\
\hline
\end{tabular}

Note: Italic represents the opt-out attribute levels

The Choice Experiment (CE) theoretical model was linked to Lancaster's (1966) characteristic theory of demand, welfare theory, and consumer theory, and also to Random Utility Theory (RUM). The CE assumed that consumers are utility maximisers, choosing between alternatives presented to them in each choice set (Table 1), and it is assumed that consumer choice reveals their preferences. Each consumer is only able to choose one alternative from the choice set at a time, bearing in mind both its cost and dimension (Alpizar, 2001). Three choice alternatives were bundled to the consumer, each with opt-out option and cost. Cost was a proxy for price premium, which the consumer may be willing to pay, given his preference for the attributes in the choice set. 


\subsection{Model Specification}

The certified palm oil value chain is investigated by estimating the preference of consumers in their choice of CSPO with environmental attributes, in Malaysia. Attributes are bundled within the CE, and presented to the respondents in a hypothetical situation, in the form of various choice sets containing steps for scenario improvement. Respondents make choices within their preferred sets, and the analyst processes their responses using statistical models.

The model used in the study was the Mixed Logit Model, considered the most popular, state-ofthe-art, discrete model, with high flexibility, such that it can be used to approximate any random utility model. The model has no stringent assumption of Independence of Irrelevant Alternatives (IIA), or other problems of CLM revealed by Dauda et al. (2015). Assuming that a sample of consumers ( $n=$ $1, \ldots . ., n)$ were faced with a choice among $i$ alternatives, in each of $t$ choice situations; utility maximising consumers will choose the bundle with the highest possible utility, which is presented in the general form of a discrete model as:

$$
U_{\text {int }}=\beta_{\mathrm{n}}^{\prime} X_{\mathrm{int}}+\varepsilon_{\mathrm{int}}
$$

$X_{\text {int }}=$ a vector of the explanatory variable

$B_{n}^{\prime}=$ a corresponding vector of taste parameters

$\varepsilon_{\text {int }}=$ independent and identically distributed (IID) extreme value type 1 , and independent of $\boldsymbol{B}_{n}^{\prime}$ and $X_{\text {int }}$.

The taste parameter vector coefficient, for each consumer $B_{n}^{\prime}$, can be broken down as the sum of the population mean $b$, and a stochastic deviation $\eta_{n}$, that represent consumer tastes in the population. Each consumer has vector $\eta_{n}$ of taste parameters, which deviates from the population mean $b$ by vector $\eta_{n}$, so $b$ can be estimated but $\eta_{n}$; cannot be observed. Thus, the utility is rewritten as:

$$
U_{\text {int }}=\left(b+\eta_{\mathrm{n}}\right) X_{\text {int }}+\varepsilon_{\text {int }}
$$

MLM deviates from CLM when common influence of $\eta_{n}$ : on ML does not exhibit the IIA property. Thus, we can allow the unobserved portion of utility $\left(\eta_{\mathrm{n}} X_{\text {int }}+\varepsilon_{\text {int }}\right)$ to correlate between the alternatives and choice sets faced by each consumer (Train, 1998).

The MLM can assume any of several distributional forms, such as normal, lognormal, and triangular, and can assume a general distribution over individuals and alternatives for $\eta_{n}$, and an IID extreme value type 1 distribution for $\varepsilon_{i n t}$. That is, $\eta_{n}$ denotes the density of $\eta_{\mathrm{n}} f\left(\eta_{\mathrm{n}} \mid \Omega\right)$ where $\Omega$ is the fixed parameter of the distribution. For a given value of $\eta_{n}$, the conditional probability for choice $i$ is logit, since the remaining error term is IDD extreme value:

$$
L_{i}(\eta)=\frac{\exp \left(\beta^{\prime} \mathrm{X}_{\mathrm{i}}+\eta_{\mathrm{i}}\right)}{\sum_{j} \exp \left(\beta^{\prime} \mathrm{X}_{\mathrm{j}}+\eta_{\mathrm{j}}\right)}
$$

Since $\eta$ is not given the unconditional choice probability is this formula, the integrated overall values of $\eta$, weighted by the density of $\eta_{i}$, are as shown in equation $\mathrm{L}$.

$$
\mathrm{P}_{\mathrm{j}}=\int L_{i} \eta\left(f\left(\eta_{\mathrm{n}} \mid \Omega\right) \mathrm{d} \eta\right.
$$

The choice probability $\operatorname{Li}(\eta)$ is a mixture of logit, with $f$ as the mixing distribution. The probability does not exhibit the well-known independence from irrelevant alternatives property IIA, and models of this kind are known as MLM (Hensher et al., 2015). 
Location of the consumer's preference on the distribution, is not known to the analyst, but can be obtained by retrieving consumer-specific preferences. Using Bayesian rule, we can define the conditional distribution as an equation (5).

$$
\mathrm{H}_{\mathrm{n}}(\beta \mid \theta)=\mathrm{L}_{\mathrm{n}}(\beta) \mathrm{g}(\beta \mid \theta) / \mathrm{P}_{\mathrm{n}}(\theta)
$$

$L_{n}(B)$ is the likelihood of an individual's choice, if they had this specific $B \cdot g(B / \vartheta)$ is the distribution in the population of $B s$ (being in the population), and $P_{n}(\vartheta)$ is the choice probability function defined in open form as:

$$
\mathrm{P}_{\mathrm{n}}(\theta)=\int L_{n}(\beta) \mathrm{g}(\beta \mid \theta) \mathrm{d} \beta
$$

We use simulation to approximate the values of the parameters, and for any given value of the parameter a value of $\eta$ is drawn from its distribution. The logit formula $3 \mathrm{~L}$ is calculated, by using draws, which is repeated several times until the model reaches convergence. The means that results, $L_{i}(\eta)^{\prime} s$, are taken as the optimal choice probability. Given the equation (below), $\mathrm{R}$ is the number of replications (that is, draws of $\eta$ ), $\eta_{i r}$ is the draw, and $S P_{i}$ is the simulated probability that an individual chooses alternative $i$. (Hensher et al., 2015).

Mean WTP value for each attribute can be computed by dividing the $B$ of the attribute (nonmonetary) in the model by the $B$ of the cost;

$$
M W T P=\frac{\beta_{x 1}}{\beta c}
$$

The value of each attribute is called implicit price, or marginal rate of substitution (MRS).

To acquaint consumers with forest attributes (passive values), like absorption of harmful $\mathrm{CO}_{2}$ emitted in the process of palm oil production, or the conservation of biodiversity, focus group discussions were held to determine the attributes, and their levels. The levels adopted for biodiversity conservation were high and moderate, while for $\mathrm{CO}_{2}$ emission were low and moderate. Choice cards were designed with pictorial illustration to facilitate respondents understanding of the choice scenarios. Previous CE studies like (Sakagami \& Sakaguchi, 2018) have reported using attributes levels with qualitative descriptions.

Table 2. Example of choice set scenario

\begin{tabular}{|c|c|c|c|}
\hline Attributes & Option 1 & Option 2 & Opt out \\
\hline RSPO Palm Oil (cooking oil) & RSPO 1-99\% Mixed & RSPO 100\% Certified & No choice \\
\hline $\begin{array}{c}\text { Biodiversity conservation } \\
\text { Emission of } \mathrm{CO}_{2} \text { gas (Climate } \\
\text { Change) }\end{array}$ & High conservation & Moderate conservation & No choice \\
\hline $\begin{array}{c}\text { Cost of premium price in } \\
\text { percentage to support RSPO }\end{array}$ & $\begin{array}{c}\text { Up to 3\% } \\
\text { Increase on price }\end{array}$ & $\begin{array}{c}\text { Up to 5\% } \\
\text { Increase on price }\end{array}$ & $\begin{array}{c}\text { At 0\% } \\
\text { increase on } \\
\text { price }\end{array}$ \\
\hline Choice Option & $\mathrm{X}$ & & \\
\hline
\end{tabular}

As a prerequisite for CE studies, we generated orthogonal design of the hypothetical market situation via design efficient (ChoiceMetrics, 2018). Attributes and levels considered for this study were bundled into 16 choice sets, divided into blocks of two questionnaires. Consumers were presented with 8 choice scenarios in each questionnaire (Table 2).

The questionnaire was designed, pre-tested, and translated to local language to ease understanding, and to elicit high response. The first part introduced the mission of the study, and the connection between oil palm and the environment. The second part asked consumers about their knowledge of CSPO, and of the statutory certifying bodies and their roles. The last part introduced 
detailed explanation of the attributes and their relationship with environment as were presented to the respondents in choice set scenarios.

\section{Results and Discussion}

\subsection{Demographic Profiles of the Respondents}

Simple descriptive statistic percentages and frequencies were used to analyse the demographic profile of the respondents. We categorised respondents into three groups based on their age, where the age bracket of $18-30$ years appeared at frequency $47.2 \%$ (152 respondents), and constituted the largest number of respondents, bracket of $31-45$ years appeared at frequency of $39.8 \%$ (128), and bracket of $46-60$ years appeared at frequency of 13\% (42 respondents). 218 of the respondents were male (67.7\%), with the remaining 104 being female (32.3\%). Monthly household income indicated that those earning below RM3000 constituted only $11.5 \%$, between RM 3001 and 5000 were $6.5 \%$ (21 respondents), between RM 5001 and 7000 were 19.9\% (64), and between RM 7001 and 9000 were $25.5 \%$ (82). The highest income participants surveyed, earning RM 9000 and above, constituted the majority of the sample with $36.6 \%$ (118). The reported level of education attainment indicated that 247 of the respondents attended university, which represented $76.7 \%$ of the sample, while for the other participants $37 \%$ had attended a polytechnic or college, $23 \%$ secondary school, $13 \%$ primary, and $2 \%$ did not have any formal schooling.

Table 3. Socio-Demographic Profile of the Respondents

\begin{tabular}{|c|c|c|}
\hline Variable & Frequency & Percentage \\
\hline Age & & \\
\hline $18-30$ years & 155 & 47.2 \\
\hline $31-45$ years & 126 & 39.8 \\
\hline $46-60$ and above & 47 & 13 \\
\hline Gender & & 67.7 \\
\hline Male & 218 & 32.3 \\
\hline Female & 104 & 11.5 \\
\hline Income & & 6.5 \\
\hline $1000-3000$ & 37 & 19.9 \\
\hline $3001-5000$ & 21 & 25.5 \\
\hline $5001-7000$ & 64 & 36.6 \\
\hline $7001-9000$ & 82 & \\
\hline 9000 and above & 118 & 76.7 \\
\hline Level of Education & & 11.5 \\
\hline University & 247 & 7.5 \\
\hline College/Polytechnic & 37 & 4.0 \\
\hline Secondary & 23 & 0.6 \\
\hline Primary & 13 & \\
\hline No Education & 2 & \\
\hline
\end{tabular}

\subsection{Consumer Knowledge of Certified Sustainable Palm Oil}

Low awareness on the issues related to CSPO has been reported in previous research, in Malaysia, and in most of the developed economies (Lange \& Coremans, 2020, Schleifer \& Sun, 2018, Ruysschaert $\&$ Salles, 2016). Our findings confirmed that almost $60 \%$ of Malaysian consumers were not aware that CSPO has not contributed to the problems associated with palm oil. Their reported knowledge of RSPO 
as a voluntary international standard indicated that $50 \%$ were aware, and $50 \%$ unaware. This result is dissimilar to MSPO survey results, which had reported that $60 \%$ of people were aware of it, while $40 \%$ were unaware. $75 \%$ of the current study respondents reported belief that all problems associated with palm oil are addressable. $75 \%$ equally agree that the production processes of palm oil are the source of the problem associated with palm oil, but not the palm oil in itself Table 4.

$71 \%$ endorsed that certification of the oil palm and palm oil can minimise the problems associated with palm oil. $60 \%$ of consumers were aware that stakeholders in the palm oil industry initiate, and determine the nature, of certifying bodies such as the RSPO and MSPO, and $40 \%$ were unaware. $67 \%$ of the respondents could only distinguish between certified and uncertified palm oil through labelling and certification, which is an expected result in that most palm (cooking) oil appears homogeneous in both colour and quality. All certified palm oil producers carry the mandate to include eco-labels on their packages. Consumers are aware of the policy, and endorsed it with almost $80 \%$ agreement. However, only $40 \%$ endorsed that certification and labelling provide assurance that sustainability standards are being met, which might indicate limited knowledge of the connection between certification and sustainability.

Table 4. Consumer Knowledge on Certified Sustainable Palm oil

\begin{tabular}{|c|c|c|c|}
\hline Code & Do you know that & Yes. Freq (\%) & No. Freq (\%) \\
\hline Know1 & $\begin{array}{c}\text { Certified Sustainable Palm Oil (CSPO) is certified as having not } \\
\text { contributed to problems associated with oil palms oil }\end{array}$ & 130(40.3) & 196(59.6) \\
\hline Know2 & $\begin{array}{c}\text { Roundtable on Sustainable Palm Oil (RSPO) certification body is } \\
\text { a voluntary international standard for palm oil certification }\end{array}$ & $159(49.3)$ & $163(50.6)$ \\
\hline Know3 & $\begin{array}{c}\text { Malaysian Sustainable Palm Oil (MSPO) is a mandatory } \\
\text { Malaysian national standard for certification of palm oil }\end{array}$ & $192(59.6)$ & $130(40.3)$ \\
\hline Know4 & the problem associated with palm oil can be addressed & $214(74.8)$ & $81(25.1)$ \\
\hline Know5 & $\begin{array}{c}\text { most of the problem is not with palm oil, but its production } \\
\text { processes }\end{array}$ & $234(74.6)$ & $88(27.3)$ \\
\hline Know6 & $\begin{array}{c}\text { certifying palm oil production processes can minimise the problem } \\
\text { associated with palm oil }\end{array}$ & $231(71.7)$ & 91(28.2) \\
\hline Know7 & $\begin{array}{c}\text { palm oil certification bodies are initiated by stakeholders in the oil } \\
\text { palm industry }\end{array}$ & $193(59.9)$ & $129(40.06)$ \\
\hline Know8 & $\begin{array}{c}\text { you can only distinguish between certified and non-certified palm } \\
\text { oil by reading the labels on the product package }\end{array}$ & $216(67.06)$ & $106(32.9)$ \\
\hline Know9 & $\begin{array}{c}\text { all certified palm oils are mandated to carry certification label on } \\
\text { the packages }\end{array}$ & $255(79.19)$ & $67(20.8)$ \\
\hline Know10 & $\begin{array}{c}\text { certification labels are assurance that palm oil has complied with a } \\
\text { sustainability standard }\end{array}$ & $130(40.3)$ & 192(59.6) \\
\hline
\end{tabular}

Interaction of the socio-demographic variables in the CLM indicated that the RSPO2 and RSPO3 coefficients were significant at the $1 \%$ level, while the $\mathrm{BIO}$, and $\mathrm{BIO} 3$ coefficients were significant at the $5 \%$ level, and the COE2 coefficient was insignificant, while the COE3 was negatively significant at the $5 \%$ level. Interaction indicated that RSPO2_EDU was significant at the 5\% level, BIO2_INC, BIO2_EDU, and BIO2_GEN were significant coefficients at the $5 \%$ level. COE_INC was significant at the $10 \%$ level.

The basic MLM model reported in Table 5-6 indicates that all attributes in the model had significant coefficients at the $1 \%$ level, and had correct apriori signs. Loglikelihood function of the basic model was -1581.719 , with a Pseudo $R^{2}$ value of 0.28090 , and an adjusted $R^{2}$ of 0.27894 . The extended model indicated that all attributes were significant, and had correct apriori expected signs. Cost attribute, and ASC signs were correct and significant at the $1 \%$ level. To ascertain model fitness, the log likelihood ratio of both models was examined for improvement alone. Log likelihood ratio in the extended model stood at -1561.572 , and in the basic model stood at -1581.719 . Pseudo $R^{2}$ in the extended model was 
0.29006, and in the basic model was 0.28090 . Thus, it was concluded that the inclusion of sociodemographic information had improved the fitness of the model.

The results generated by the simple model indicated the price premium increment, consumer MWTP for mass balance supply value chain, as $6.33 \%$, which compared with the proposed $3 \%$ to $5 \%$ price premium above the existing stock price of the cooking oil. The segregated value chain recorded result was $5.77 \%$. The consumer MWTP result for moderate biodiversity conservation stood at $4.90 \%$, for high conservation at $5.58 \%$, for moderate emission of $\mathrm{CO}_{2}$ at $4.21 \%$, and for low emission of $\mathrm{CO}_{2}$ at $1.48 \%$.

Table 5. Choice experiment results for CLM and MLM

\begin{tabular}{|c|c|c|c|c|}
\hline Variables & Simple CLM & Interaction CLM & Simple MLM & Interaction MLM \\
\hline Variable & Coeff (std error) & Coeff (std error) & Coeff (std error) & Coeff (std Error) \\
\hline RSPO2 & $1.8399(.1266)^{\star \star \star}$ & $1.9785(.2383)^{\star * *}$ & $1.2710(.1880)^{\star \star *}$ & $1.9688(.2745)^{\star \star \star}$ \\
\hline RSPO3 & $1.6764(.0794)^{\star \star *}$ & $.7488(.1796)^{\star \star \star}$ & $.7854(.1787)^{\star \star \star}$ & $.7650(.1807)^{\star * *}$ \\
\hline $\mathrm{BIO} 2$ & $1.4237(.1163)^{\star \star \star}$ & $1.4720(.4231)^{\star *}$ & $.7957(.1620)^{\star \star \star}$ & $1.4385(.3686)^{\star * \star}$ \\
\hline $\mathrm{BIO} 3$ & $1.6203(.0804)^{\star \star \star}$ & $.6559(.1856)^{\star *}$ & $.6955(.1808)^{\star \star \star}$ & $.6714(.1821)^{\star \star *}$ \\
\hline COE2 & $1.2234(.1329)^{\star * \star}$ & $.1763(.3015)$ & $.6352(.1701)^{\star \star *}$ & $.6443(.1829)^{\star \star \star}$ \\
\hline \multirow[t]{2}{*}{ COE3 } & $.4323(.0761)^{\star \star *}$ & $-.5153(.1849)^{\star *}$ & $-.4829(.1628)^{\star *}$ & $-.5001(.1635)^{\star \star}$ \\
\hline & - & - & \multicolumn{2}{|c|}{$\begin{array}{l}\text { Non-random parameter in utility } \\
\text { function }\end{array}$} \\
\hline COST & $-.2902(.0167)^{\star * *}$ & $-.3821(.0239)^{\star * *}$ & $-1.7994(.3144)^{\star * \star}$ & $-1.8720(.3224)^{\star * *}$ \\
\hline ASC & - & $-1.9096(.3236)^{\star \star \star}$ & $-.3704(.0203)^{\star \star *}$ & $-.3797(.0254)^{\star \star *}$ \\
\hline RSPO2_EDU & - & $-.4748(.1176)^{\star \star}$ & - & $-.4640(.1309)^{\star \star \star}$ \\
\hline BIO2_GEN & - & $-.5650(.2280)^{\star *}$ & - & $-.5491(.2084)^{\star \star}$ \\
\hline BIO2_EDU & - & $-.3782(.1182)^{\star \star}$ & - & $-.3935(.1055)^{\star \star \star}$ \\
\hline BIO2_INC & - & $.2685(.1020)^{\star *}$ & - & $.2857(.0912)^{\star *}$ \\
\hline \multirow[t]{2}{*}{ COE2_INC } & - & $.1923(.1080)^{\star}$ & - & - \\
\hline & & & \multicolumn{2}{|c|}{$\begin{array}{c}\text { Derived standard deviations of } \\
\text { parameter distributions }\end{array}$} \\
\hline RSPO2 & - & - & $.2774(87.80)$ & $.0015(43.12)$ \\
\hline RSPO3 & - & - & $.0001(22.90)$ & $.0084(12.09)$ \\
\hline $\mathrm{BIO} 2$ & - & - & $.0003(32.49)$ & $.0064(20.54)$ \\
\hline $\mathrm{BIO}$ & - & - & $.0003(15.94)$ & $.0079(8.20)$ \\
\hline COE2 & - & - & $.0001(29.61)$ & $.0023(15.64)$ \\
\hline COE3 & - & - & $.3534(10.59)$ & $.0023(6.45)$ \\
\hline \multicolumn{5}{|c|}{ Summary Statistics } \\
\hline $\begin{array}{c}\text { Number of } \\
\text { observations }\end{array}$ & 2576 & 2576 & 2576 & 2576 \\
\hline Log-likelihood $(L(\beta))$ & -1597.775 & -1559.959 & -1581.719 & -1561.572 \\
\hline $\begin{array}{l}\text { Log Likelihood, No } \\
\text { coeff }(L(0))\end{array}$ & -2199.5955 & -2199.5955 & -2199.5955 & -2199.5955 \\
\hline Pseudo $\mathrm{R}^{2}$ & .27360 & .29080 & .28090 & .29006 \\
\hline Adjusted $\mathrm{R}^{2}$ & .27261 & .28900 & .27894 & .28757 \\
\hline
\end{tabular}

Interaction of the CLM model recorded MWTP of 5.17\% premium increase for the mass balance supply value chain model, while segregation of the CLM model recorded $1.97 \%$ premium increase, 
moderate conservation of biodiversity $3.85 \%$, high conservation $1.71 \%$, moderate $\mathrm{CO}_{2}$ emission $0.46 \%$, and low emission $1.34 \%$ premium increase. To account for parameter heterogeneity, MLM was subsequently applied, following Sakagami \& Sakaguchi, (2018), who applied the method to overcome the difficulty of revealing consumer preference using only CLM.

Simple MLM attributes indicated that mass balance value chain attracted a $3.43 \%$ premium, segregation $2.12 \%$, moderate biodiversity conservation $2.14 \%$, high conservation $3.85 \%$ premium, and moderate conservation $1.87 \%$, moderate conservation $1.71 \%$, and low conservation a $1.30 \%$ premium increase.

Interaction model attributes indicated that mass balance value chain attracted a $5.10 \%$ premium, segregation value chain $2.02 \%$, moderate biodiversity conservation $3.88 \%$ and high biodiversity $1.77 \%$, moderate emission of $\mathrm{CO}_{2} 1.68 \%$ increase, and low emission of $\mathrm{CO}_{2}$ attracted only $1.35 \%$ premium increase.

Table 6. Mean Willingness to Pay or Marginal Rate of Substitution among the attributes

\begin{tabular}{|c|c|c|c|c|}
\hline & Simple CLM & Interaction CLM & Simple MLM & Interaction MLM \\
\hline Attributes & MWTP\% & MWTP\% & MWTP\% & MWTP\% \\
\hline RSPO2 & $6.33^{\star * \star}$ & $5.17^{\star * *}$ & $3.43^{\star \star \star}$ & $5.10^{\star \star \star}$ \\
\hline RSPO3 & $5.77^{* * *}$ & $1.95^{\star \star}$ & $2.12^{\star \star \star}$ & $2.02^{\star \star *}$ \\
\hline $\mathrm{BIO} 2$ & $4.90^{\star * \star}$ & $3.85^{\star \star \star}$ & $2.14^{* *}$ & $3.88^{\star \star \star}$ \\
\hline $\mathrm{BIO}$ & $5.58^{\star * \star}$ & $1.71^{\star *}$ & $1.87^{\star}$ & $1.77^{\star *}$ \\
\hline COE2 & $4.21^{\star \star \star}$ & 0.46 & $1.71^{\star}$ & $1.68^{*}$ \\
\hline COE3 & $1.48^{\star \star \star}$ & $1.34^{*}$ & 1.30 & 1.35 \\
\hline
\end{tabular}

\section{Discussion}

Consumer knowledge on issues related to CSPO, determined in the survey, indicated higher awareness of MSPO than of RSPO, while there was a dearth of awareness of issues related to palm oil certification and labelling. Consumers acknowledged that palm oil is not the problem in itself, but its production processes, which could be an indication of the need for sustainability in palm oil production. However, consumers were confident that issues related to palm oil were addressable, but expressed reservation on the efficacy of certification to address all the problems associated with palm oil. When palm oil production represents a trade-off between economy and ecology, addressing all palm oil problems may jeopardize the economic gain accrued from palm oil production.

The MLM result indicated that consumer WTP for certified palm cooking oil, produced through an RSPO value chain of mass balance, attracted higher premium allotment. This was true even though mass balance accommodates a mixture of palm oil products from both certified and conventional sources, compared to the $100 \%$ certified product of the segregated value chain process. Addressing global environmental problems, with moderate levels of biodiversity conservation and $\mathrm{CO}_{2}$ emission reduction, were allocated higher premium than for high conservation and low emission options. The choice pattern was considered to be coherent with CLM.

Conservation of biodiversity was considered more important than reduction of $\mathrm{CO}_{2}$ emission, similar to findings in study of certified wood products in Japan by Sakagami \& Sakaguchi, (2018). Through their choices, consumers expressed that buying certified palm oil that conserved biodiversity would give them more utility, than buying certified palm oil to reduce global warming. It is concluded that consumers give higher preference to value chain processes, because adherence to the value chain will automatically address other problems associated with palm oil, since value chain and conservation, or emission reduction, are functionally related and coherently attached. 


\section{Conclusion and Policy Implications}

The current study was able highlight the role of consumer knowledge in influencing consumer choice of sustainable products. Despite shortcomings pertinent to CE results, it could be established that both consumer preferences, and WTP for price premium on CSPO, can be stimulated for palm oil that promises to conserve biodiversity and reduce global warming, which result should be considered while setting sustainability standards for palm oil.

The study also established that consumers value RSPO certified palm oil above conventional products, which is in harmony with previous studies which have indicated that consumers are willing to pay price premium on products that help to conserve biodiversity, and reduce global warming. Consumer WTP price premiums for environmentally certified wood were presented in studies by Aguilar \& Vlosky (2007), and Sakagami \& Sakaguchi (2018).

The current study also adds weight to previous studies (Gassler \& Spiller, 2018; De Jonge et al., 2015) which advocated the introduction and adoption of value chain (mass balance/book and claim) models, thus relaxing the stringent model of segregation/trace and track. The current findings indicate consumer support and willingness to pay high premium for mixed RSPO palm oil. Although, in the view of Gassler \& Spiller (2018), adoption of mass balance, or book and claim, can no longer guarantee traceability of the palm oil for consumers, but it can stimulate the smooth take up of certification and ecolabelling of palm oil, thus generating premium to the processors in Malaysia.

The current study contributes to the existing literature on consumer preferences for certified green products, especially palm oil and its by-products, while further study on certified palm oil should incorporate behavioural intention, and perceptions of the consumer WTP, in choosing CSPO.

The policy implications of the study should provide insight, and be useful in assessing policy adoption and implementation, for stakeholders including government, palm oil stakeholders, value chain members, conservationists, environmental non-governmental organizations, and consumers of palm oil and its products. The current global shift towards green consumerism will be achieved once the end consumer becomes enlightened, and involved in sustainable consumption. This may arguably mean that consumers will choose to purchase sustainable palm oil, which may translate to conservation of biodiversity, and reduction in the emission of harmful $\mathrm{CO}_{2}$. Adoption of a mass balance value chain compromise may be a means of rescue of sustainable palm oil product, from becoming shelved into a niche market.

The findings should provide insight to the RSPO, environmental NGOs, and other palm oil stakeholders, in furthering the cause of sustainable palm oil, towards certification and ecolabeling of RSPO palm oil (cooking oil) and other palm oil products.

\section{Funding}

The authors extend their appreciation to Universiti Putra Malaysia for its support of this research through the award of Geran Putra (GP-IPS/2018/9623800).

\section{References}

1. Aguilar, F. X., \& Vlosky, R. P. (2007). Consumer willingness to pay price premiums for environmentally certified wood products in the U.S. Forest Policy and Economics, 9(8), 1100-1112. https://doi.org/10.1016/j.forpol.2006.12.001

2. Alpizar, F. (2001). Using Choice Experiments for Non-Market Valuation. 1-37.

3. Bateman, I. J., Coombes, E., Fitzherbert, E., Binner, A., Bad'ura, T., Carbone, C., Fisher, B., Naidoo, R., \& Watkinson, A. R. (2015). Conserving tropical biodiversity via market forces and spatial targeting. Proceedings of the National Academy of Sciences of the United States of America, 112(24), 7408-7413. https://doi.org/10.1073/pnas.1406484112 
4. Borrello, M., Annunziata, A., \& Vecchio, R. (2019). Sustainability of palm oil: Drivers of consumers' preferences. Sustainability (Switzerland), 11(18), 1-12. https://doi.org/10.3390/su11184818

5. Bougherara And Grolleau. (2004). Could Ecolabeling Mitigate Market Failures? An Analysis Applied to Agrofood. Working Paper.

6. Caswell, J. A., \& Padberg, D. I. (1992). Toward a More Comprehensive Theory of Food Labels. American Journal of Agricultural Economics, 74(2), 460-468. https://doi.org/10.2307/1242500

7. Choicemetrics. (2018). Ngene 1.2 USER MANUAL \&amp; REFERENCE GUIDE The Cutting Edge in Experimental Design End-User License Agreement. 241. www.choice-metrics.com

8. Dauda, S. A., Yacob, M. R., \& Radam, A. (2015). Household's willingness to pay for heterogeneous attributes of drinking water quality and services improvement: an application of choice experiment. Applied Water Science, 5(3), 253-259. https://doi.org/10.1007/s13201-014-0186-6

9. De Jonge, J., Van Der Lans, I. A., \& Van Trijp, H. C. M. (2015). Different shades of grey: Compromise products to encourage animal friendly consumption. Food Quality and Preference, 45, 87-99. https://doi.org/10.1016/j.foodqual.2015.06.001

10.Disdier, A. C., Marette, S., \& Millet, G. (2013). Are consumers concerned about palm oil? Evidence from a lab experiment. Food Policy, 43, 180-189. https://doi.org/10.1016/j.foodpol.2013.09.003

11.Gassler, B., \& Spiller, A. (2018). Is it all in the MIX? Consumer preferences for segregated and mass balance certified sustainable palm oil. Journal of Cleaner Production, 195(1169), 21-31. https://doi.org/10.1016/j.jclepro.2018.05.039

12.Giam, X., Mani, L., Koh, L. P., \& Tan, H. T. W. (2016). Saving Tropical Forests by Knowing What We Consume. Conservation Letters. https://doi.org/10.1111/conl.12209

13.Hensher, D. A., Rose, J. M., \& Greene, W. H. (2015). Applied choice analysis. Applied Choice Analysis, January, 1-1188. https://doi.org/10.1007/9781316136232

14.Hinkes, C., \& Christoph-Schulz, I. (2020). No palm oil or certified sustainable palm oil? Heterogeneous consumer preferences and the role of information. Sustainability (Switzerland), 12(18), 1-26. https://doi.org/10.3390/su12187257

15.Ian J. Bateman, E. C. (2009). Saving sumatra's species: combining economics and ecology to define an efficient and self-sustaining program for inducing conservation within oil palm plantations. CSERGE Working Paper EDM 09-03, 53.

16.Jensen, K. L., Jakus, P. M., English, B. C., \& Menard, J. (2004). Consumers' Willingness to Pay for EcoCertified Wood Products. Journal of Agricultural and Applied Economics, 36(3), 617-626. https://doi.org/10.1017/s1074070800026900

17.Jones, K. R., Venter, O., Fuller, R. A., Allan, J. R., Maxwell, S. L., Negret, P. J., \& Watson, J. E. M. (2018). One-third of global protected land is under intense human pressure. Science, 360(6390), 788-791. https://doi.org/10.1126/science.aap9565

18.Kaffashi, S., Shamsudin, M. N., Sidique, S. F., Bazrbachi, A., Radam, A., Rahim, K. A., \& Adam, S. U. (2016). Choice experiment attributes selection: Problems and approaches in a modal shift study in Klang Valley, Malaysia. Asian Social Science, 12(1), 75-83. https://doi.org/10.5539/ass.v12n1p75

19.Lange, F., \& Coremans, L. (2020). The role of consumer knowledge in reducing the demand for palm oil. Environmental Conservation, 47(2), 84-88. https://doi.org/10.1017/\$0376892920000053

20.Loureiro, M., \& Mccluskey, J. (2000). Consumer preferences and willingness to pay for food labeling: A discussion of empirical studies. Journal of Food Distribution Research, 34(3), 95-102.

21.Noor And Hua. (2016). International research journal of humanities \& social science. Cooking Oil Management in Cafeteria Operator: A Review, 3942(IV), 79-88.

22.Ostfeld, R., Howarth, D., Reiner, D., \& Krasny, P. (2019). Peeling back the label - Exploring sustainable palm oil ecolabelling and consumption in the United Kingdom. Environmental Research Letters, 14(1). https://doi.org/10.1088/1748-9326/aaf0e4

23.Qureshi, M. I., Khan, N., Ahmad Hassan Gillani, S. M., \& Raza, H. (2020). A systematic review of past decade of mobile learning: What we learned and where to go. International Journal of Interactive Mobile Technologies, 14(6), 67-81. https://doi.org/10.3991/IJIM.V14I06.13479

24.Richardson, B. (2015). Making a Market for Sustainability: The Commodification of Certified Palm Oil. New Political Economy, 20(4), 545-568. https://doi.org/10.1080/13563467.2014.923829 
25.Ruysschaert, D., \& Salles, D. (2016). The strategies and effectiveness of conservation ngos in the global voluntary standards: The case of the roundtable on sustainable palm-oil. Conservation and Society, 14(2), 73-85. https://doi.org/10.4103/0972-4923.186332

26.Sakagami, M., \& Sakaguchi, D. (2018). Estimating preferences for wood products with environmental attributes. Forests, 9(1). https://doi.org/10.3390/f9010041

27.Schleifer, P., \& Sun, Y. (2018). Emerging markets and private governance: the political economy of sustainable palm oil in China and India. Review of International Political Economy, 25(2), 190-214. https://doi.org/10.1080/09692290.2017.1418759

28.Smith, B. G. (2008). Developing sustainable food supply chains. Philosophical Transactions of the Royal Society B: Biological Sciences, 363(1492), 849-861. https://doi.org/10.1098/rstb.2007.2187

29.Sundaraja, C. S., Hine, D. W., \& Lykins, A. (2020). Confronting the palm oil crisis: Identifying behaviours for targeted interventions. Environmental Science and Policy, 103(August), 99-106. https://doi.org/10.1016/j.envsci.2019.08.004

30.Train, K. E. (n.d.). Discrete Choice Methods with Simulation.

31.Vergura, D. T., Zerbini, C., \& Luceri, B. (2019). "Palm oil free" vs "sustainable palm oil": the impact of claims on consumer perception. British Food Journal, 121(9), 2027-2035. https://doi.org/10.1108/BFJ-01-2019-0020 